IMEJ: Islamic Management and Empowerment Journal

Volume 2, Number 2, Desember 2020. p. 133 - 150

P-ISSN:2685-953X; e-ISSN:2686-0317

DOI: $10.18326 /$ imej.v2i2.133-150

website: http://e-journal.iainsalatiga.ac.id/index.php/imej

\title{
Pemberdayaan Nelayan dalam Mambangun Kekuatan Ekonomi Melalui Pengolahan Ikan Di Desa Karangagung
}

\author{
A. Fahmi Zakariya \\ Institut Agama Islam Negeri Kudus, Indonesia \\ fahmizakariya@gmail.com
}

\begin{abstract}
Karangagung Village is a coastal village with abundant fish potential. This study aims to build the economic strength of the community through fishermen fish processing businesses. Therefore, this study uses a qualitative method with the Participatory Action Research (PAR) approach. The data collection techniques used interviews, focus group discussion. Through the PAR approach, researchers encourage the involvement of fisherwomen communities to identify problems and potentials, then take empowerment actions. The results showed that empowerment efforts have encouraged active involvement of fishermen, increasing skills to develop fish products in realizing mutual welfare.
\end{abstract}

Keywords: Fishermen Empowerment, Fish Processing.

\begin{abstract}
Abstrak
Desa Karangagung merupakan desa kawasan pesisir dengan potensi ikan yang melimpah. Penelitian ini bertujuan untuk membangun kekuatan ekonomi masyarakat melalui usaha olahan ikan nelayan. Oleh karenanya, penelitian ini menggunakan motode kualitatif dengan pendekatan Participatory Action Research (PAR). Adapun teknik pengumpulan data menggunakan wawancara, focus group discussion. Melalui pendekatan PAR, peneliti mendorong keterlibatan komunitas perempuan nelayan untuk melakukan identifikasi persoalan dan potensi, lalu melakukan aksi pemberdayaan. Hasil penelitian menunjukkan bahwa upaya pemberdayaan telah mendorong adanya keterlibatan aktif nelayan, meningkatkan keterampilan untuk pengembangkan produk ikan dalam mewujudkan kesejahteraan bersama.
\end{abstract}

Kata Kunci: Pemberdayaan Nelayan, Pengolahan Ikan 


\section{Pendahuluan}

Posisi geografis kepulauan Indonesia sangat strategis karena merupakan pusat lalu lintas maritim antar benua. Indonesia juga memiliki kedaulatan terhadap laut wilayahnya meliputi; perairan pedalaman, perairan nusantara, dan laut teritorial (sepanjang 12 mil dari garis dasar). Disamping itu ada juga zona tambahan Indonesia, yang memiliki hak-hak berdaulat dan kewenangan tertentu. Selain itu, ada juga Zona Ekonomi Eksklusif Indonesia (ZEEI) sejauh 200 mil dari garis pangkal, di mana Indonesia mempunyai hak-hak berdaulat atas kekayaan alam (perikanan), kewenangan untuk memelihara lingkungan laut, mengatur dan mengizinkan penelitian ilmiah kelautan, pemberian ijin pembangunan pulaupulau buatan, instalasi dan bangunan-bangunan lainnya (Lasabuda, 2013).

Wilayah perairan beserta sumberdaya alamnya memiliki makna strategis bagi pengembangan ekonomi Indonesia, karena dapat diandalkan sebagai salah satu pilar ekonomi nasional. Berdasarkan Undang-Undang Nomor 32 Tahun 2004 tentang Pemerintahan Daerah, ditegaskan bahwa daerah yang memiliki wilayah laut diberikan kewenangan untuk mengelola sumberdaya di wilayah laut. Kewenangan daerah dalam mengelola wilayah lautnya, yaitu paling jauh 12 mil-laut untuk provinsi, yang dihitung dari garis pantai ke arah laut lepas dan/atau ke arah perairan kepulauan, dan 1/3 dari itu untuk kabupaten/kota (Ramdhan, 2013).

Masyarakat pesisir didefinisikan sebagai kelompok orang yang tinggal di daerah pesisir dan sumber kehidupan perekonomiannya bergantung secara langsung pada pemanfaatan sumberdaya laut dan pesisir. Definisi ini bisa dikembangkan lebih jauh karena pada dasarnya banyak orang yang hidupnya bergantung pada sumberdaya laut. Mereka terdiri dari nelayan pemilik, buruh nelayan, pembudidaya ikan, pedagang ikan, pengolah ikan, supplier faktor sarana produksi perikanan. Dalam bidang non-perikanan, masyarakat pesisir bisa terdiri dari penjual jasa pariwisata, penjual jasa transportasi, serta kelompok masyarakat lainnya yang memanfaatkan sumberdaya non-hayati laut dan pesisir untuk menyokong kehidupannya (Nikijuluw, 2001).

Pemberdayaan masyarakat pesisir dapat dilakukan dengan upaya mambangun masyarakat agar potensi laut dapat dikelola dengan baik. Salah satu startegi yang harus dilakukan adalah memperkuat komunitas yang ada di masyarakat dan mengembangkan kualitas sumber daya manusia (SDM) dengan 
jalan meningkatkan keterampilan ekonomi masyarakat (Sujana, 2020).

Misi utama pemberdayaan masyarakat adalah bukan sekedar memberikan bantuan konsumtif melainkan bantuan produktif yang membuat si penerima memiliki kapasitas untuk menolong dirinya sendiri (Hasan dan Andriany, 2015). Masyarakat pesisir dapat dikembangkan untuk meningkatkan kesejahteraan ekonomi masyarakat. Komunitas nelayan dapat meningkatkan sumber daya manusia dan keterampilan mengolah produkproduk olahan perikanan yang sesui dengan tuntutan pasar serta dapat menghidari ancaman-ancaman yang dapat menghambat peningkatan kesejahteraan ekonomi masyarakat pesisir (Butarbutar, 2020).

Desa Karangagung merupakan salah satu dari 19 desa yang berada di kawasan pesisir di Kecamatan Palang, Kabupaten Tuban yang dihuni oleh 2689 KK 10146 jiwa terdiri dari laki-laki 5121 jiwa dan perempuan 5024 jiwa. Kurang lebih 2072 orang mengandalkan sumber penghidupan sebagai nelayan. Terdiri dari 1962 Nelayan, 110 Buruh nelayan. Nelayan di desa ini memiliki 525 kapal dengan kapasitas 7 GT sebanyak 145 buah dan kapasitas 7-30 GT sebanyak 380 buah dengan dilengkapi dengan alat tangkap berupa Jaring, Pukat, bubu dan Pancing. Hasil tangkapan ikan masyarakat Desa Karangagung sangat beragam yaitu: tongkol/tuna, terumpa, rebon, bilis/teri, tengiri, rajungan, rejong, udang ronggeng, cumi, udang, kerapu, kakap dan lainnya. (Profil Desa Sistem Informasi Nelayan Desa Karangagung, 2018).

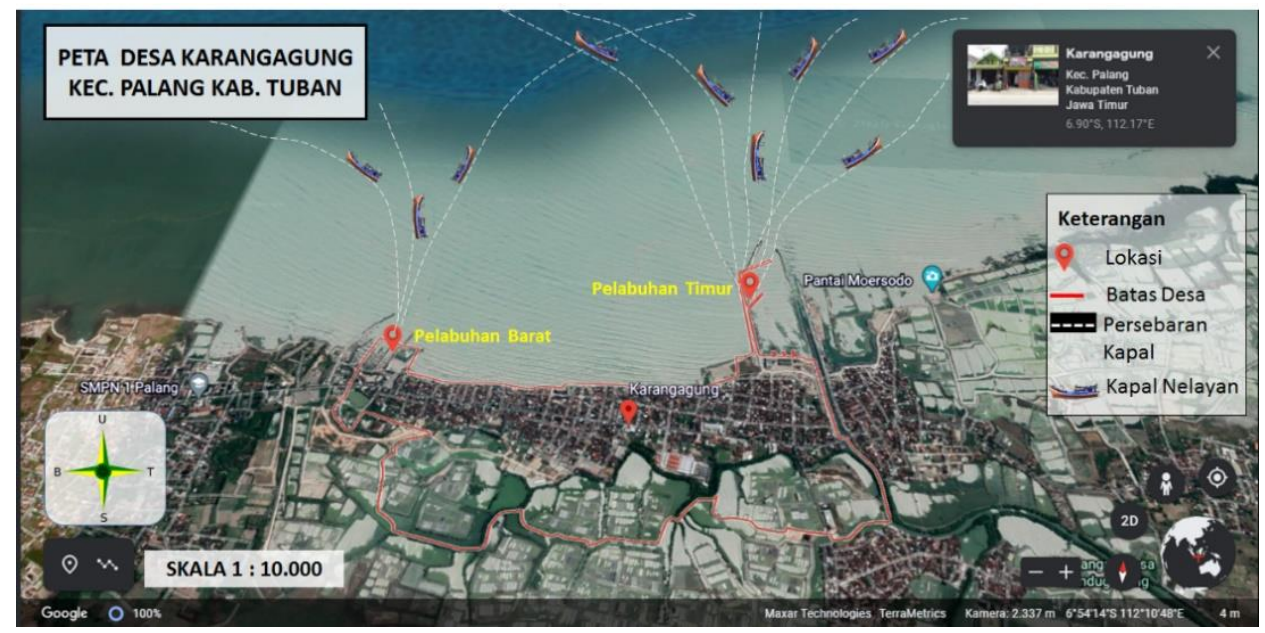

Gambar 1. Peta Desa Karangagung Kecamatan Palang Tuban

Sumber : peta google earth 2018

Di Desa Karangagung terdapat dua pelabuhan yakni Pelabuhan Karangagung Barat dan Pelabuhann Karangaagung Timur. Kedua pelabuhan ini 
merupakan potensi yang dimiliki olah Desa Karangang yang menjadi roda penggerak kegiatan perekonomian. Perbedaan dari kedua pelabutan tersebut dapat dilihat dari jenis kapalnya. Pada Pelabuhan Karangagung Barat jenis kapalnya adalah kapal-kapal kecil yang wilayah jalur lautnya cederung pendek, dengan durasi saat mencari ikan berkisaran 3 sampai 8 jam. Sedangkan untuk Pelabuhan Karangagung Timur jenis-jenis kepalnya beragam, namun kebanyakan adalah kapal-kapal besar yang jalur lautnya panjang, dengan durasi pencarian ikan harian bahkan sampai mingguan.

Pada penelitian masyarakat nelayan Desa Karangagung berfokus pada pemberdayaan masyarakat dalam mengembangan sektor ekonomi melalui pengolahan ikan hasil tangkapan nelayan. Pada penelitian sebelumnya di Desa Karangangung berfokus pada isu kesehatan lingkungan tentang hubungan antara kepemilikan jamban dengan kejadian diare di Desa Karanggung (Putranti, 2013). Sedangakan pada penelitian ini ingin melihat problem masyarakat yang berhubungan dengan hasil tangkapan ikan yang menjadi ponopang perokonomian masyarakat dalam memperoleh pendapatan. Dari hasil temuan penelitian ini dikembangkan dalam proses pemberdayaan masyarakat sehingga masyarakat dapat berupaya menyelesaikan problem yang dihadapi dalam rangka mewujudkan masyarakat mandiri.

Pemberdayaan masyarakat nelayan dalam membangun kekuatan ekonomi masyarakat melalui kegiatan pengolahan ikan di Desa Karangagung merupakan program yang diinisiasi untuk mengembangan inovasi-inovasi masyarakat dalam mengolah ikan menjadi produk yang bisa bertahan lama dan layak jual. Proses kegiatan pemberdayaan nelayan dilakukan secara kolektif dimulai dengan mencari dan menganalisa data secara bersama, kemudian dirumuskan dengan keputusan bersama untuk melakukan produksi pengolahan ikan.

Tujuan dari kegiatan pemberdayaan ini adalah mendorong inovasi masyarakat dalam mengolah ikan, mempunyi produk olahan ikan yang bisa memenuhi kebutuhan pasar dan menambah pendapatan masyarakat. Hasil dari kegiatan pemberdayaan ini diharapkan agar masyarakat bisa terdorong dalam mengembangan usaha keberlanjutan seperti UMKM dan industri rumah tang ga produksi olahan ikan Desa Karangagung. Selain itu, penelitian ini diharapkan menjadi referensi pemerintah desa dalam membangung RPJM desa dari sisi pemberdayaan ekonomi masyarakat. 


\section{Metode Penelitian}

Penelitian ini menggunakan metode Participatory Action Research (PAR). Alasan memilih PAR sebagai metode penelitian karena tidak hanya menguntungkan peneliti saja tetapi juga memberikan manfaat yang lebih besar untuk masyarakat (Ali dan Hasan, 2019). PAR adalah penelitian yang ditandai oleh keterlibatan aktif dari masyarakat yang menjadi kelompok sasaran. Penelitian ini menempatkan masyarakat yang menjadi kelompok sasaran sebagai subyek dalam proses kegiatan, dan bukan obyek. Dalam PAR peneliti menempatkan diri sebagai insider bukan outsider atau antara subyek dan obyek (Ridho, 2019).

PAR adalah suatu cara membangun jembatan untuk menghubungkan orang. Jenis penelitian ini adalah suatu proses pencarian pengembangan pengetahuan praktis dalam memahami kondisi sosial, politik, lingkungan, atau ekonomi. Penelitian ini mencari sesuatu untuk menghubungkan proses penelitian ke dalam proses perubahan sosial (Kindo, 2007). Menurut Koch and Krilik (dalam Wahyuni, 2016, 97) PAR merupakan merupakan proses di mana peneliti dan partisipan bekerja bersama secara sistematis dalam menggali dan menyelesaikan permasalahan.

Metode PAR ini menggunakan pengumpulan data data melalui wawancara, pemetaan, analisa kalender musim, Focus Groud Discussion (FGD). Semua hasil analisa dan keputusan bersama berdasarkan data dan temuan di lapangan. Dalam penelitian ini masyarakat sebagai peneliti dan pelaku dalam proses pengorganisasian, sedangkan peneliti sebagai faslitator atau rekan masyarakat.

Pada penelitian ini dilakukan di Desa Karangagung, Kecamatan Palang Kabupaten Tuban, yang berada di wilayah Pesisir Utara Pantai Jawa. Desa Karangagung terletak ujung timur Kabupaten Tuban yang berbatasan langsung dengan Kabupaten Lamongan. Penelitian ini dilaksanakan selama selama 3 bulan (Januari-Maret 2019). Sedangkan yang menjadi subyek dalam kegiatan penelitian ini adalah para perempuan istri nelayan yang setiap hari ada di rumah.

Penelitian ini diawali dari beberapa wawancara kepada masyarakat, kemudian dianalisis dengan pemetaan kawasan untuk melihat kondisi desa secara visual. Hasil peta dan wawancara dilanjutkan dengan FGD bersama masyarakat. FGD dilakukan untuk melihat kalender musim pendapatan 
nelayan, serta pengalaman masyarakat dalam pengolahan ikan. Setelah itu dilaksanakan dengan melakukan uji coba pengalaman masyarakat dalam mengolah ikan yang potensial. Lalu dilakukan analisa usaha agar bisa menjadi kegiatan produk usaha nelayan.

\section{Hasil dan Pembahasan \\ Indentifikasi Permasalahan dalam Prespektif Lokal}

Menjalankan kehidupan bermasyarakat tidak akan pernah luput dari proses interaksi sosial. Dalam proses interaksi tersebut akan sangat diperlukan adanya komunikasi sosial, dan di dalam komunikasi sosial setiap individu tentu mempunyai pikiran, visi dan misi yang berbeda (Aini, dkk, 2018). Proses inkulturasi di masyarakat sebagai salah satu bentuk interaksi sosial. Dalam upaya melihat kondisi dan persoalan di dalam masyarakat maka perlu adanya inkultulasi di dalam masyarakat, agar bisa menemukan problem masyarakat secara benar. Inkultulasi juga sebagai bentuk membangun kepercayaan antara masyarakat dengan peneliti, sehingga dengan adanya inkulturasi kedekatan komunitas dengan peneliti dapat terbentuk secara baik.

Persoalan yang terjadi di masyarakat tidak hanya perlu diketahui melalui perspektif eksternal atau dari pihak ketiga tetapi juga perlu diupayakan untuk selfreflection atau mengenali potensi diri (Soedarwo, 2017). Pengenalan potensi atau permasalahan diri secara mandiri harus dilakukan dan diupayakan karena merupakan langkah awal yang baik dan produktif bagi masyarakat. Kesadaran ini penting dalam melihat diri dan lingkungannya secara kritis karena merupakan bekal dasar untuk membangun sense of belonging sekaligus sebagai bekal dalam menguatkan perekonomian desa (Perguna, 2019).

Untuk melihat kondisi dan permasalahan masyarakat nelayan Desa Karangagung dilakukan dengan cara Focus Group Discussion dengan menggunakan kalender musim. Kegiatan mengungkap kalender musim yang dilakukan pada masyarakat bertujuan untuk melihat kondisi jenis-jenis ikan yang sering didapat oleh nelayan sesuai perjalanan waktu musiman.

Hasil laut yang sering didapatkan oleh nelayan merupakan hasil pendapatan meraka sehari-hari. Dengan demikian, besar kecil pendapatan hasil ikan yang didapatkan tergantung pada musim. Masyarakat nelayan juga mempunyai hitungan sendiri dalam membaca musim. Mereka mampu melihat peluang apa saja jenis ikan yang muncul di musim tertentu. Hal ini digunakan untuk persiapan alat tangkap ikan sebelum pergi ke laut. Sehingga ikan yang didapatkan bisa tepat 
sasaran. Namun yang menjadi kendala adalah ikan ada, akan tetapi cuaca ektrim yang tidak mendukung sehingga membuat nelayan tidak bisa melaut. Hal ini berdampak pada ikan langka saat di pasar, karena nelayan memilih tidak melaut akibat cuaca buruk.

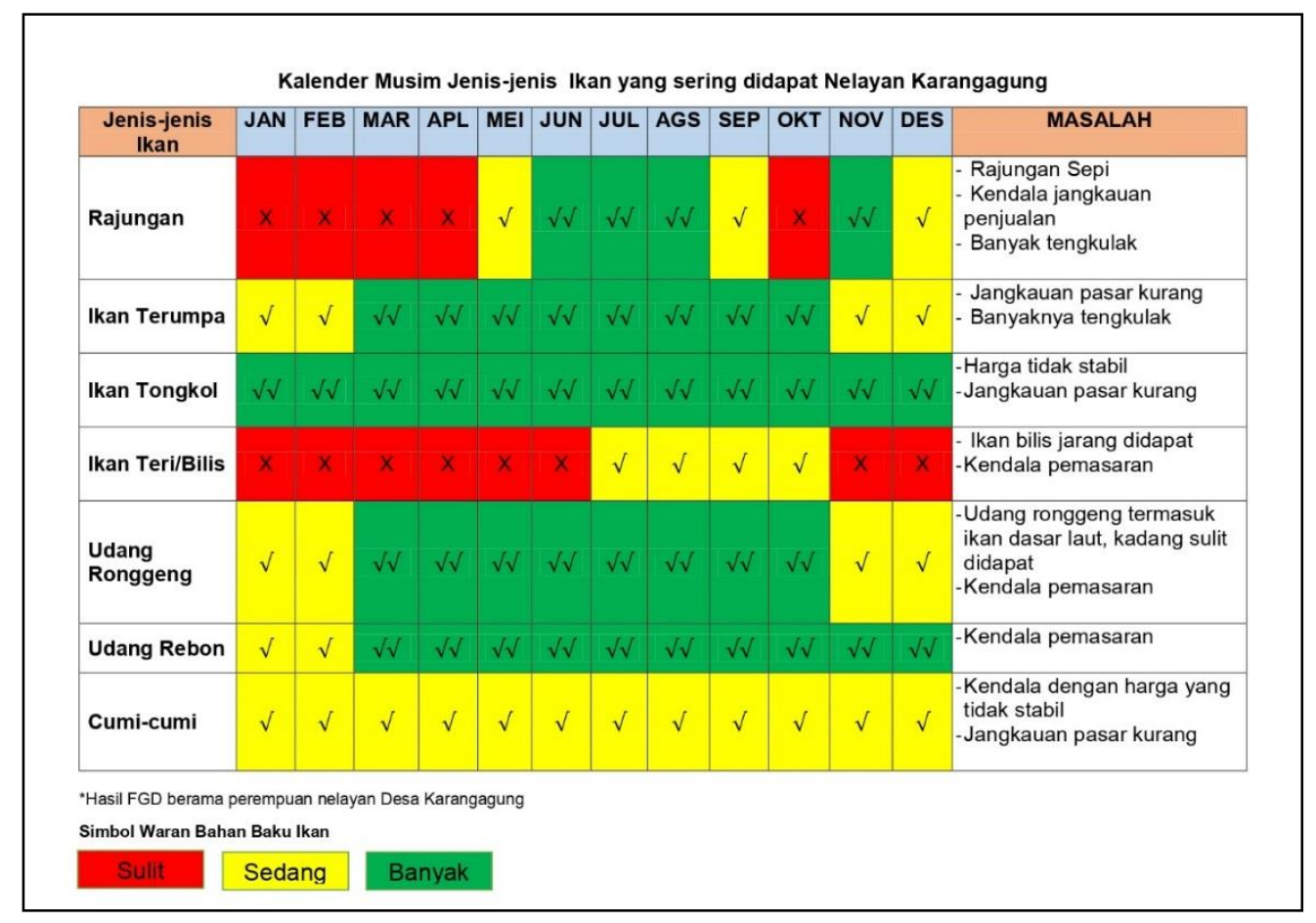

Tabel 1. Kalender musim jenis ikan yang sering didapat oleh nelayan

Sumber : FGD bersama perempuan nelayan

Penelusuran peneliti dalam melihat masalah yang sering dihadapi nelayan dari hasil tangkapan ikan adalah problem pemasaran dan banyaknya rantai tengkulak. Rata-tata nelayan setalah melaut hasil tangkapan ikan langsung diturunkan di dekat Tempat Pelalangan Ikan (TPA). Saat itu penjulan ikan langsung diambil alih oleh tengkulak. Nelayan hanya menunggu hasil dari penjulan ikan tangkapan tersebut. Besar kecilnya pendapatan yang didapat tergantung pada tengkulak yang menjual ikan. Ini yang membuat harga ikan yang didapatkan tidak stabil, apalagi juga dipengaruhi oleh musim yang tidak menentu dalam mendapatkan ikan. Untuk perluasan pemasaran hasil ikan tangkapan tengkulak mempunyai peran, yang menjadi distributor pemasaran adalah tengkulak langsung, sedangkan nelayan hanya menunggu hasil.

Faktor yang menjadi problem masalah hasil tangkapan ikan nelayan adalah ikan yang sudah ditangkap harus segara terjual, karena ikan sifatnya mudah busuk, kalau tidak cepat diolah ikan akan cepat berubah warna, tekstur, dan baunya. Ini 
juga yang mempengaruhi harga ikan jadi. Pengolahan hasil tangkapan ikan dari nelayan jika yang didapat melimpah biasanya diolah menjadi ikan asin yang dikeringkan, ikan asap, dan ikan yang didinginkan. Ini yang menjadi problem potensi yang melimpah namun tidak bisa bertahan lama karena kondisi ikan yang cepat busuk.

\section{Memproduksi Pengetahuan Masyarakat}

Masyarakat pesisir mempunyai sifat-sifat atau karakteristik tertentu yang unik. Sifat ini sangat erat kaitannya dengan sifat usaha di bidang perikanan itu sendiri. Karena sifat usaha-usaha dari perikanan sangat dipengaruhi oleh faktorfaktor seperti lingkungan, musim, dan pasar, maka karakteristik masyarakat pesisir juga dipengaruhi oleh faktor-faktor tersebut (Wahyudin, 2003). Begitu pula pada masyarakat nelayan Desa Karanggaung dalam usaha perikanan yang menjadi tiang penyangga kegiatan perputaran perekonomian warga. Ekonomi masyarakat dapat berkembang tergantung pada perolehan ikan yang didapat oleh nelayan.

Masyarakat nelayan Desa Karangagung sangat menggantungkan pada pola musim dan pola pasar dalam melakukan usaha perikanan. Kondisi musim bisa mempengaruhi tangkapan ikan yang didapat. Misalnya saat memperoleh tangkapan ikan yang sangat tinggi, namun pada hari tertentu juga bisa memperoleh ikan yang rendah bahkan tidak mendapatkan ikan sama sekali. Kondisi pasar juga bisa mempengaruhi pendapatan, karena sifat ikan yang mudah membusuk maka ikan harus cepat dijual. Kondisi seperti inilah yang mempengaruhi sistem pasar yang tidak stabil. Ikan yang didapat pada hari itu harus dijual untuk memenuhi kebutuhan hidup masyarakat nelayan.

Kondisi permasalahan ini membuat masyarakat melakukan inovasi-inovasi dalam upaya memperoleh pendapatan tambahan. Dengan melihat kondisi musim dan kondisi pasar yang tidak menentu membuat masyarakat berusaha untuk tetap bisa bertahan hidup yakni dengan mencoba mengolah hasil laut. Pembuatan olahan tersebut dilakukan jika perolehan ikan yang melimpah namun harga jual ikan yang menurun, sehingga hasil olahan tersebut bisa dijual dan dikosumsi pada saat musim tertentu dengan tangkapan hasil ikan yang rendah, dan kondisi yang menyebabkan nelayan tidak bisa melaut.

Ikan yang merupakan pangan sumber protein ini memiliki kelemahan yaitu tidak dapat bertahan lama. Komoditas ini cepat mengalami kerusakan sehingga memerlukan pengolahan lebih lanjut. Kegiatan pengolahan ikan banyak dilakukan dengan berbagai cara, seperti pembuatan abon ikan, ikan kaleng, ikan asin, ikan 
asap, dan sebagainya. Untuk itu keberadaan industri perikanan sangat diperlukan, agar ikan menjadi suatu produk yang siap untuk dikonsumsi oleh masyarakat (Howara, 2013). Hasil usaha pengolahan yang dilakukan olah masyarakat nelayan adalah inovasi masyarakat untuk mengembangkan perekonomian lokal.

Pengalaman dan pengetahuan masyarakat dalam melakukan inovasi pengolahan ikan merupakan pengetahuan kearifan lokal, dengan melakukan uji coba sampai olahan ikan tersebut bisa dikonsumsi masyarakat dan menjadi produk. Dengan demikian, penting mengetahui aktor-aktor lokal yang pernah melakukan uji coba olahan ikan untuk menemukenali produk-produk olahan apa yang sudah masyarakat buat dengan bahan dasar ikan.

\begin{tabular}{|l|l|c|}
\hline \multicolumn{3}{|c|}{ Jenis-Jenis olahan Ikan Desa Karangagung } \\
\hline No & \multicolumn{1}{|c|}{ Unit Usaha } & Pelaku \\
\hline 1. & Kerupuk Lemi & $\begin{array}{c}\text { Heriyana, } \\
\text { Yuliatin }\end{array}$ \\
\hline 2. & Kerupuk Ikan Terumpa & Hermin \\
\hline 3. & Kerupuk Ikan Tongkol & Martib \\
\hline 4. & Teri Krispi (Bilis, Samban) & Herlina \\
\hline 5 & Kerupuk Udang Ronggeng & Yuliatin \\
\hline 6. & Terasi & Riyanti \\
\hline 7. & Cumi Krispi & Sri Rahayu \\
\hline 8. & Stik Ikan & Kelompok \\
\hline 9. & Petis Rajungan & Hanan \\
\hline 10. & Nughet Ikan & Mulyono \\
\hline
\end{tabular}

Tabel 2. Pengolahan ikan yang pernah dibuat masyarakat

Sumber : FGD bersama perempuan nelayan

Identifikasi temuan pengalaman masyarakat nelayan dalam mengolah ikan hasil tangkapan cukup beragam. Namun dari hasil temuan tersebut yang paling banyak dan sering dilakukan masyarakat dalam mengolah ikan adalah dioalah menjadi kerupuk. Karena banyak jenis-jenis ikan yang bisa dijadikan bahan dasar untuk membuat kerupuk. Namun dalam pengolahan ikan menjadi kerupuk yang dilakukan masyarakat hanya skala kecil, untuk konsumsi pribadi, dan jika ada pesanan saja. Produk olahan yang lain juga mempunyai potensi untuk dikembangkan karena masyarakat sudah mempunyai pengalaman untuk membuat. Dari hasil identifikasi temuan produk-produk olahan tersebut merupakan media untuk mengembangkan ekonomi masyarakat.

\section{Pemberdayaan Masyarakat dalam Membangun Kekuatan Ekonomi}


Pemberdayaan adalah upaya untuk membangun kemampuan masyarakat dengan mendorong, memotivasi, membangkitkan kesadaran akan potensi yang dimiliki dan berupaya untuk mengembangkan potensi itu menjadi tindakan nyata (Zubaedi, 2014). Tujuan dari pemberdayaan masyarakat ialah mendorong "power" atau kekuatan pada masyarakat, agar masyarakat mempunyai kekuasan dalam kehidupannya mereka sendiri. Pemberdayaan masyarakat sebagai bentuk upaya untuk mengangkat hargat dan martabat manusia dari kondisi yang membuat meraka terbelenggu.

Gerakan ekonomi kerakyatan adalah salah satu wujud dari beberapa gerakan kultural dan struktural dalam pemberdayaan ekonomi masyarakat. Gerakan ini memiliki pijakan realitas ditengah masyarakat. Bahkan pada founding father telah memformalisasikannya dalam konstitusi Republik Indonesia (Sasano, 2008). Salah satu upaya untuk memberdayakan potensi ekonomi masyarakat serta membangun masyarakat yang mandiri adalah melahirkan sebanyak-banyaknya wirausahawan baru. Asumsinya sederhana, kewirausahaan pada dasarnya adalah kemandirian, terutama kemandirian ekonomi, dan kemandirian adalah keberdayaan (Machengdrawati, 2001).

Pembangunan ekonomi pada hakikatnya adalah pembangunan masyarakat. Dalam pembangunan ekonomi akan banyak ditampilkan masalah-masalah kemasyarakatan terutama yang menyangkut nilai-nilai masyarakat yang bersangkutan. Pengembangan ekonomi masyarakat merupakan salah satu pemberdayaan masyarakat. Dengan perekonomian masyarakat yang meningkat meraka akan mempunyai kekuatan dalam menjalani kehidupan berkelanjutan. Sektor pengembangan ekonomi masyarakat bisa dimulai dari melihat potensipotensi yang ada di desa sebagai pemenuhan kebutuhan primer.

Dari pengalaman masyarakat, usaha membuat pengelolaan ikan sebagai langkah awal dalam mendorong gerakan ekonomi masyarakat. Sumber daya manusia yang dimiliki juga cukup memberikan kontribusi terhadap keberhasilan program. Masyarakat memiliki keterampilan yang cukup variatif (Puspitasari, 2020). Melihat pengalaman masyarakat tersebut merupakan langkah penelitin dalam melakukan kegiatan pemberdayaan melalui inisiatif program pengolahan hasil laut. Proses pelaksanaan pemberdayaan yang dilakukan peneliti bersama masyarakat dalam mengembangan olahan ikan dengan beberapa tahapan.

Pada tahapan pemberdayaan masyarakat dalam membangun kekuatan ekonomi yang dilakukan peneliti menggunakan beberapa tahapan yang dilakukan secara bersama dengan menggunakan media belajar bersama komunitas. Tahapan 
dilakukan adalah uji coba produksi, packaging, dan marketing. Uji coba ini merupakan praktik untuk membangun kesadaran masyarakat dalam mengolah hasil laut sebagai usaha untuk melakukan kegiatan kewirausahaan.

Pertama, uji coba produksi pengolahan ikan. Pada tahap ini peneliti bersama masyarakat mencoba untuk belajar bersama-sama tentang cara mengolah ikan yang nantinya akan menjadi produk unggulan masyarakat. Dari hasil FGD menemukan kesepakatan membuat produk olahan ikan tongkol menjadi produk kerupuk ikan. Alasannya karena ikan tongkol selalu ada setiap musim sehingga bahan baku mudah untuk didapatkan. Pelaksanaan uji coba pembuatan kerupuk ikan tongkol dimulai dengan menyiapkan alat dan bahan. Alat yang dipersiapkan adalah pisau, panci, kompor, ember, sendok, telenan, panci, sutil, blander, wajan, tempat penjemur kerupuk. Sedangkan bahan yang dipersiapkan adalah ikan tongkol segar, tepun tapioca, bawang putih, garam, penyedap rasa, dan air hangat.
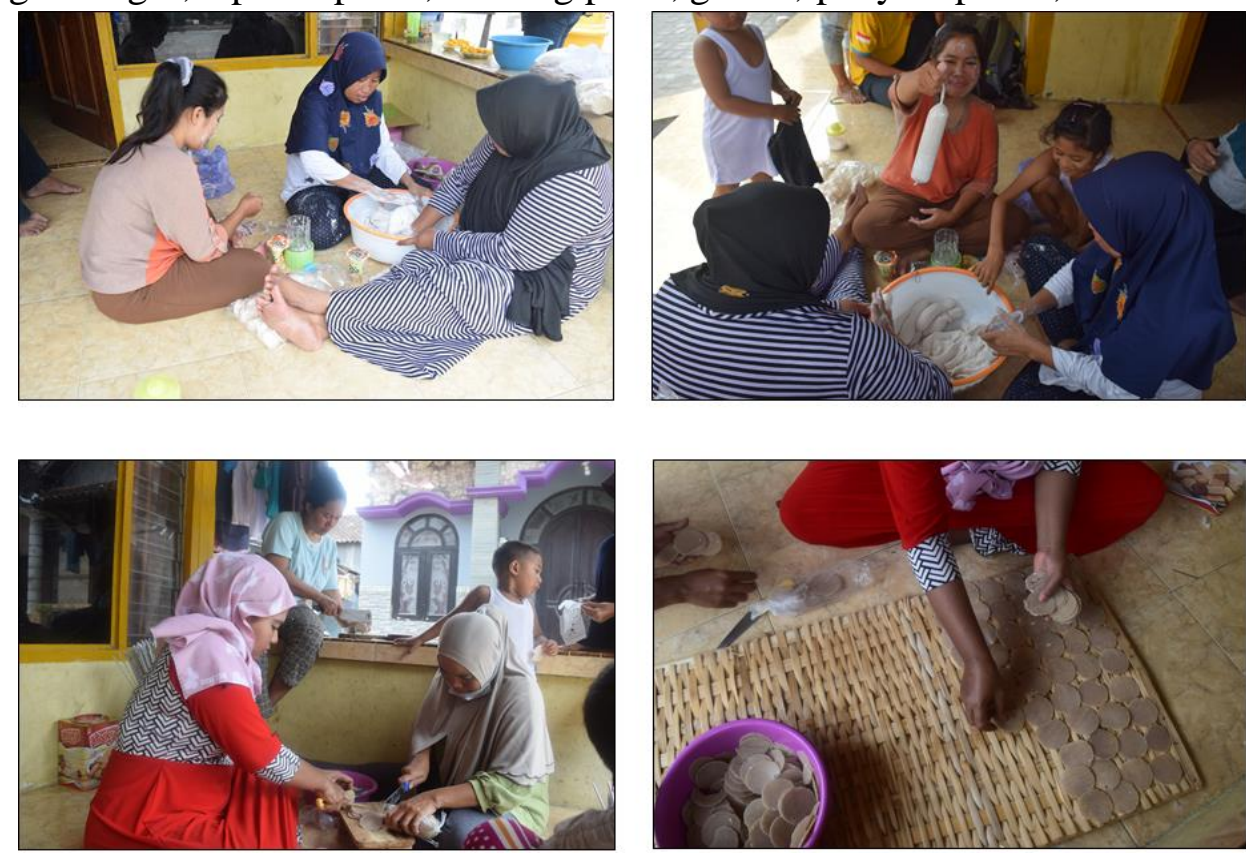

Gambar 2. Uji coba membuat kerupuk kerupuk ikan tongkol

Sumber: dokumentasi peneliti

Setelah alat dan bahan sudah siap uji coba, pembuatan kerupuk dimulai secara bersama-sama antara masyarakat dengan peneliti untuk melihat secara detail alur pembuatan. Langkah selanjutnya setelah ikan tongkol diolah menjadi kerupuk adalah melakukan pengamatan rasa untuk melihat bagaimana rasa olahan yang sudah dibuat apakah layak dikonsumsi atau tidak. Pengamatan rasa dengan tester kerupuk dan siap dikonsumsi. Kerupuk tersebut dibagikan ke semua beberapa orang. Setelah itu orang tersebut disuruh menila bagaimana rasanya 
mulai dari asin, manis, gurih, pedas, dan pahit. Dari hasil penilaian tersebut digunakan untuk menganalisis komposisi olahan kerupuk ikan tongkol. Sehingga analisa rasa tersebut bisa menjadi acuan standar rasa yang disukai konsumen.

Kedua, uji coba packaging (pengemasan). Uji coba pengemasan dilakukan untuk membuat kemasan yang menarik sehingga produk yang telah dibuat masyarakat bisa mempunyai daya tarik untuk dijual pada konsumen. Kemasan tidak hanya berfunsi untuk membukus produk olahan, tetapi juga untuk melindungi produk agar bisa bertahan lama, selain itu kemasan juga sebagai pemberi informasi bagi konsumen (Budi, 2017). Oleh karena itu perlu adanya label produk yang bisa dilihat oleh konsumen.
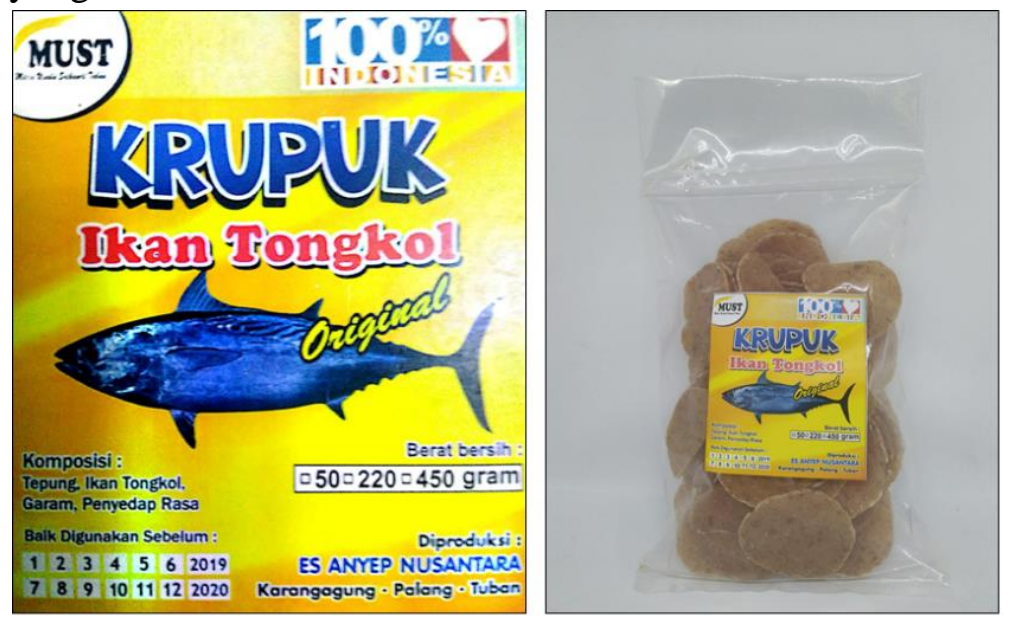

Gambar 3. Uji coba pengemasan hasil olahan keruppuk ikan tongkol

Sumber: dokumentasi peneliti

Label pangan adalah setiap keterangan mengenai pangan yang berbentuk gambar, tulisan, kombinasi keduanya, atau bentuk lain yang disertakan pada pangan, dimasukkan ke dalam, ditempelkan pada, atau merupakan bagian kemasan pangan, yang selanjutnya dalam Peraturan pemerintah disebut label (Peraturan pemerintah Indonesia, 1999). Pembuatan label produk kerupuk ikan tongkol pa da kegiatan uji coba packaging adalah dengan membuat nama produk, nama dagang, komposisi, nama dan alamat produksi, isi berat bersih, dan tanggal kedaluwarsa.

Ketiga, uji coba marketing dan analisa ekonomi. Menurut Philip Kotler (dalam Cenedi, 2000) prinsip ada 4 elemen penting dalam strategi pemasarana yaitu: Product (produk), Price (harga), Place (tempat), dan Promotion (promosi). Uji coba pemasaran merupakan salah satu distribusi yang digunakan untuk menawarkan produk yang sudah dibuat dengan nilai hasil yang dapat menjadi 
timbal baik nilai dan produk.

Pada tahap uji coba yang dilakukan melakukan pamasaran konvesional dan pemasaran digital. Pemasaran konvensional dilakukan dengan memasarkan ke pasar-pasar tradisional, toko klontong, dan tempat oleh-oleh. Untuk pemasaran digital dilakukan melalui melalui sosial media seperti whatshapp, facebook, dan istagram. Hal ini merupakan tahap awal dari uji coba pemasaran dan belum pada tahap pemasaran melalui E-Commerce. Pada tahap uji coba pemasaran dilakukan analisa ekonomi yang dilakukan peneliti bersama masyarakat, analisa ekonomi digunakan untuk menentukan standar harga produk dapat dilihat pada table yang tersaji sebagai berikut:

\begin{tabular}{|c|c|c|c|}
\hline Modal & \multicolumn{2}{|c|}{ Biaya Produksi } & \\
\hline Ikan Tongkol & $0,5 \mathrm{~kg}$ & Rp. 15.000 & \\
\hline Tepung Tapioka & $2 \mathrm{~kg}$ & Rp. 25.000 & \\
\hline Bawang Putih & 2 ons & Rp. 5.000 & \\
\hline Garam & 2 sendok & Rp. 200 & \\
\hline Air Hangat & 1 liter & Rp. 200 & \\
\hline Penyedap Rasa & 2 bungkus & $\operatorname{Rp} 2.000$ & \\
\hline Kantong Plastik & Bandel & Rp. 5.000 & \\
\hline \multicolumn{3}{|c|}{ Jumlah } & Rp. 52.400 \\
\hline & \multicolumn{2}{|c|}{ Biaya Operasional } & \\
\hline Tenaga Kerja & \multicolumn{2}{|c|}{ Rp. 3000} & \\
\hline Gas LPG & \multicolumn{2}{|l|}{ Rp. 5.000} & \\
\hline Listrik & \multicolumn{2}{|l|}{ Rp. 500} & \\
\hline & \multicolumn{2}{|l|}{ Jumlah } & Rp. 8.500 \\
\hline \multicolumn{3}{|c|}{ Jumlah } & Rp. 60.900 \\
\hline
\end{tabular}

Tabel 3. Analisa usaha produk kerupuk ikan tongkol

Dari penjelasan tabel tersebut diketahui bahwa penyusutan produk setelah kering menjadi $2 \mathrm{~kg}$ kerupuk ikan tongkol kering. Setiap $2 \mathrm{~kg}$ menjadi 8 kemasan kerupuk dengan berat 250 gram dengan harga 10.000. Jadi setiap $2 \mathrm{~kg}$ menjadi Rp. 80.000 dikurangi biaya modal Rp. 60.900 sehingga laba Rp. 19.100. Dari hasil penjualan dengan produksi sebesar $2 \mathrm{~kg}$ akan mendapatkan laba Rp.19.100, namun dalam analisa ini adalah jika dijual secara langsung sebelum dipotong jika ada reseller. Jika ada reseller maka laba akan dikurangi Rp.1.000 karena reseller mendapat keuntungan Rp.1.000. Jika produksi lebih banyak maka biaya modal 
akan turun karena pembelian biaya yang bisa ditotal langsung sehingga hasilnya dapat semakin meningkat.

Upaya-upaya pendampingan yang dilakukan peneliti bersama komunitas dampingan telah mampu mendorong adanya partisipasi masyarakat khususnya dari kalangan perempuan yang berprofesi sebagai nelayan. Mereka berhasil terdorong untuk mengikuti berbagai proses pemberdayaan ekonomi mulai dari memahami persoalan, memanfaatkan potensi, merencanakan dan melaksanakan program hingga menikmati hasil yang diperoleh. Begitu juga dengan hasil yang dicapai disetiap kegiatan, terlihat mulai menampakkan outcome yang menggemberikan.

\section{Kesimpulan}

Pemberdayaan masyarakat merupakan upaya untuk mambangun kesadaran masyarakat agar mempunyai kekuatan untuk mengatasi persoalan yang dihadapi. Sehingga masyarakat tersebut bisa mandiri dalam menjalankan kehidupan yang berkelanjutan. Pemberdayaan masyarakat dapat dilakukan melalui pengembangan potensi-potensi yang ada untuk menyelesaikan problem yang terjadi. Upaya pengembangan potensi dapat diketahui dari sisi pengetahuan dan pengalaman masyarakat sebagai basis untuk membangun ekonomi masyarakat yang mandiri.

Proses pendampingan dan pemberdayaan masyarakat nelayan Desa Karangagung dilakukan dengan beberapa tahap, yakni; mengetahui kondisi desa dan masyarakat, melakukan riset partisipatif, lalu merencanakan dan melakukan gerakan-gerakan aksi kolektif. Dari pola pemberdayaan ini diharapkan ada perubahan yang bisa menjadi mendorong kemandirian masyarakat.

Setelah melalui berbagai kegiatan pendampingan, masyarakat didorong untuk berinovasi dalam mengembangkan usaha olahan ikan yang bisa dijual sesui kebutuhan pasar. Masyarakat dapat mengelola usaha ikan dengan inovasi masyarakat sendiri. Dari hasil usaha pengolahan ikan tersebut terlihat bagaimana masyarakat nelayan mampu berwirausaha dan mempunyai pendapatan tambahan dalam rangka mewujudkan kesejahteraan bersama.

\section{Daftar Pustaka}

Aini, A. I., Khaudli, M. I., \& Suprapto, R. (2018). Pemberdayaan Ekonomi Masyarakat melalui Pemasaran Wisata Kuliner Jajanan Tradisoional di Desa Cantuk Kabupaten Banyuwangi. Engagement: Jurnal Pengabdian Kepada Masyarakat, 2(2), 168-175. 
Ali, M., \& Hasan, S. (2019). Da'wah bi al-Hal in Empowering Campus-Assisted Community through Waste Bank Management. Ilmu Dakwah: Academic Journal for Homiletic Studies, 13(2), 201-219.

Budi, F. S., Herawati, D., Purnomo, J., Sehabudin, U., \& Nugroho, T. (2017). Peningkatan kualitas dan diversifikasi produk ikan teri untuk pemberdayaan masyarakat di Desa Saramaake, Halmahera Timur. Agrokreatif Jurnal Ilmiah Pengabdian kepada Masyarakat, 3(2), 89-99.

Butarbutar, D. N., Sintani, L., \& Harinie, L. T. (2020). Peningkatan Kesejahteraan Ekonomi Masyarakat Pesisir Melalui Pemberdayaan Perempuan. Journal of Environment and Management, 1(1), 31-39.

Cenadi, C. S. (2000). Peranan desain kemasan dalam dunia pemasaran. Nirmana, 2(2).

Hasan, S., \& Andriany, D. (2014). Pengantar CSR, Sejarah, Pengertian dan Praksis. Yogyakarta: Pustaka Pelajar.

Howara, D. (2013). Strategi pengembangan pengolahan hasil perikanan di kabupaten donggala. Agroland: Jurnal Ilmu-ilmu Pertanian, 20(1), 75-81.

Indonesia, P. R. (1999). Peraturan Pemerintah Republik Indonesia Nomor 69 Tahun 1999 tentang Label dan Iklan Pangan. Lembaran Negara Republik Indonesia, (131).

Kindon, S., Pain, R., \& Kesby, M. (Eds.). (2007). Participatory action research approaches and methods: Connecting people, participation and place (Vol. 22). Routledge.

Lasabuda, R. (2013). Pembangunan wilayah pesisir dan lautan dalam perspektif Negara Kepulauan Republik Indonesia. Jurnal Ilmiah Platax, 1(2), 92-101. Machendrawati, Nanih, Agus Ahmad Safei. (2001). Pengembangan Masyarakat Islam dari Ideologi, Strategi, sampai Tradisi. Bandung: PT Remaja Rosdakarya

Nikijuluw, V. P. (2001). Populasi dan sosial ekonomi masyarakat pesisir serta strategi pemberdayaan mereka dalam konteks pengelolaan sumberdaya pesisir secara terpadu. Bogor (ID): Pusat Kajian Sumberdaya pesisir dan lautan, Institut Pertanian Bogor.

Ramdhan, M., \& Arifin, T. (2013). Aplikasi sistem informasi geografis dalam penilaian proporsi luas laut Indonesia. Jurnal Ilmiah Geomatika, 19(2), 141-146.

Ridho, M. Z. (2019). Signifikansi Metode (PAR) Dalam Pemberdayaan Ekonomi Umat (BAZDA Kabupaten Serang). Dedikasi: Journal of Community Engagment, 1(3), 1-13.

Sasono, A. 2008. Rakyat Bangkit Bangun Martabat. Jakarta: Pustaka Alvabet.

Soedarwo, V. S. D. (2017). Pemberdayaan Masyarakat Melalui Pendidikan 
Nonformal Berbasis Potensi Lokal dalam Membangun Desa Wisata Adat. Jurnal Sosiologi Pendidikan Humanis, 2(2), 96-102.

Sujana, I. W., Al Zarliani, W. O., \& Hastuti, H. (2020). Pemberdayaan Ekonomi Masyarakat Pesisir Melalui Pengolahan Rumput Laut. Jurnal Pengabdian Pada Masyarakat MEMBANGUN NEGERI, 4(1), 24-33.

Profil Desa Sistem Informasi Nelayan (SIN) 2018 Desa Karangagung, Kecamatan Palang Kabupaten Tuban.

Puspitasari, A. R., \& Wiyatmoko, A. (2020). Pemberdayaan Kampung Kreasi Warna-warni Lorong Mari oleh PT Pertamina (Persero) RU III Plaju. Islamic Management and Empowerment Journal, 2(1).

Putranti, D. C. M. S., \& Sulistyorini, L. (2013). Hubungan antara kepemilikan jamban dengan kejadian diare di Desa Karangagung Kecamatan Palang Kabupaten Tuban. Jurnal Kesehatan Lingkungan, 7(1), 54-63.

Wahyuni, T. (2016). Strategi Pengembangan Usaha dengan Metode PAR (Participatory Action Research) pada Usaha Pemfilletan dan Pengolahan Ikan di UKM Jaya Utama Kecamatan Mayangan, Kota Probolinggo, Jawa Timur (Doctoral dissertation, Universitas Brawijaya).

Wahyudin, Y. (2003). Sistem sosial ekonomi dan budaya masyarakat pesisir. Makalah disampaikan pada pelatihan Pengelolaan Kawasan Konservasi Perairan, tanggal, 5.

Zubaedi. 20114. Pembangunan Masyarakat: Wacana dan Praktek. Jakarta, Kencana Pranadamedia Graup.

\section{Internet}

Peta Spasial Geographic Information System (GIS) Google Earth, https://earth.google.com/web/search/desa+karangagung+palang/@ _ $\underline{6.89868045,112.164659,1.54242 \mathrm{a}, 2345.63418753 \mathrm{~d}, 35 \mathrm{y}, 0 \mathrm{~h}, 45 \mathrm{t}, 0 \mathrm{r} / \mathrm{data}=\mathrm{Co}}$ IBGlgSUgolMHgyZTc3OTVmNDliNTY2ZjMxOjB4ZWE4YzUxZDFhY zZiNzI3NxkcmaK305kbwCGEIbyH1QpcQCoXZGVzYSBrYXJhbmdhZ3 VuZyBwYWxhbmcYAiABIiYKJAng2DQC2tYawBEOiqdf4fOcwBkfKf2 BuSpcQCEvNpy3ONhbQCgC

\section{Wawancara:}

Wawancara dengan komunitas masyarakat nelayan, januari-maret 2019

\section{Observasi:}

Observasi dengan komunitas masyarakat nelayan, januari-maret 2019 